\title{
The Effective Reasons for the Rise and fall of Abbasids State
}

\author{
Ahmad Lamei Giv1,* \\ ${ }_{1 *}^{*}$ Faculty of Literature and Humanities, Department of Persian language and Literature, University of Birjand, Birjand, Iran \\ Corresponding Author: Ahmad.lamei2@birjand.ac.ir
}

\section{Doi:10.5901/mjss.2016.v7n3s1p449}

\section{Abstract}

Bani Abbas were the descendants of Muhammad's uncle Abbas. They used this dependence to the prophethood family well in order to achieve power and managed more than five centuries of Muslim rule as his successor. Despite the prosperity and power of the state in the first period, they gradually weakened so that the last Abbasid caliph was killed by the Mongol invasion to Baghdad in $656 \mathrm{Hiji}$ and the government collapsed. Using an analytical- explanatory method, article examines the factors affecting the rise and fall of the Abbasids. Since the main research concentration is investigaion of effective reasons in the rise and fall of Abbasid state, this article explains the reasons using a descriptive-analytical method by comparison of reports from former and classic references. This study uncovers that the Persians' unsparing efforts, support by parties and groups opposed to the Umayyads, regular and robust communication network between Ale Abbas and the inviters and creating a strong connection between bless Alawites and Abbasids have important roles in the rise of Abbasids. On the other hand, a change in policy towards Persians and Alawites, pushing the two groups of caliphate system, the incompetence of some caliphs and influence of Turkish element on the Abbasid caliphate causes weakness and decadence of the Abbasids.

Keywords: Abbasids Caliphate, rise, fall, Persians.

\section{Introduction}

The Abbasids root reaches to Abbas ibn Abdolmotaleb ibn Hashem ibn Abdol Manaf, the uncle of the Prophet. Bani Hashem that had been removed completely from the political scene of the Muslim world since the year 41 Hiji began revolutionary activity as a rival and possible successor to the Umayyads. From around the year 100 Hijri, Bani Hashim was divided into two branches of Alawites Abbasids. Finally, building a large organization by the help of the Alawites and Persians' support, the Abbasids managed to to be in charge of a caliphate system. They established one of the most important Muslim powers and ruled the Islamic world for centuries; they overthrown by the Mongols. In addition to search and explain the rise and fall of the Abbasids, this article tries to put an effective step to further understanding of the dynasty and their rulers who either increase the power of the state by their wise policies or weaken the state by their unwise policies. Accordingly, research questions are as follows:

1. What elements were used by the Abbasids to achieve the power and how could they attract the vote of Persians and Alawites to use their advocacy?

2. Why the Abbasids missed the support of Persians and Alawites after achieving the power and tended to the Turks?

3. What are the reasons for weakness and collapse of the Abbasids?

\section{Hypotheses}

1. Abbasids could establish their own rule based on systematic and secret organization, taking the advantage of proximity and kinship with the Prophet (PBUH), non-Arab hatred of the Umayyad, the deceptive motto of "Satisfaction of the family of Muhammad", and Persians and Alawites' steadfastness.

2. Abbasids had gradually changed their policy after the coming to power, lost the support of Persians and Alawites by eliminating the Alawites and killing Iranian leaders of the movement, and turned to the Turks because of the weakness of the caliphate and the of numerous Persian uprisings.

3. The weakness of many of the Abbasid caliphs and the influence foreign agents such as the Turks, Buwayhid, Seljuk Turks and Kharazmshahian on the caliphate system was weakening the government. 


\section{Literature Review}

Both Arab researchers and contemporary scholars have conducted several studies on the Abbasids state. Tabari History, Yaghoubi history, The Meadows of Gold, The History of Caliphs, Fakhri history etc. are ancient sources used in this article. Contemporary sources are The Abbasid State by Muhammad Soheil Taqoush and Kezri's The Abbasids' state and History of the Abbasid Caliphate from beginning to end of the Buwayhid, Qaderis' Evolution in the Abbasid Caliphate from Start of Legitimacy to Collapse of the Foundations. The related article is Azizollah Bayat's History of Iran from the advent of Islam to Diyalameh. Nevertheless, the causes of the rise and fall of the Abbasid have not been independently investigated in any of these sources.

\section{Emergence of the Abbasids}

The Abbasids were the descendants of Abbass bin Abdulmotaleb, the uncle of the Prophet (PBUH). Abbas and his son Abdullah (D. 68 Hijri), were not very interested in politics so that Abbas had no a remarkable company in political process after the death of the Prophet (PBUH) and Abdullah was a scientific figure rather than a political person. Ali ibn Abdollah ibn Abbas (D. 118 Hiji). After release for Walid's perison, he settled in Hamimeh, a village near Bahrol Mayt. The Abbasids could provide one of the most important political developments in the history of Islam through security and taking advantages of the communication situations in Hamimeh (Yaghoobi, 1987, 2 / 125-126; Dhahabi, 1987, 1 / 89-90).

It should be noted that there was a dispute over the presidency of the Kaaba between the Bani Hashim and Bani Umayyad before the advent of Islam. After Muawiyah and Yazid's tyranny, scope of the dispute increased against Ali ibn Abi Talib (AS) and his family so that it led to the extinction of the Umayyads government. (Bayat, 1991: 234).

Some historians consider the Abbasid revolution as an Iranian revolution against the Arabic government; some regard it as merely a revolution against the rule of the Umayyad to shorten their hands from the government and replacing them instead of the Abbasids. Some speak of the certainty of this transformation because of developments in the Muslim world during the first Hiji century. It can be said that the development is the result of lopsided Umayyads' policy against non-Arab people and some Arab groups, the Abbasids exploited it in their own favor (Taqoush, 2004: 5).

The Abbasids occupied the caliphate place with the overthrow of the the Umayyads. Muslims and Islamic lands witnessed division and duality of caliphate for the first time by the the continuation of Umayyad Caliphate in Andalusia. In order to justify its legitimacy, especially in relation to the Umayyad caliphs, the Abbasids were not only decieved people but also they legitimized the Caliphate in relation to some traditions attributed to the Prophet. The traditions or some predictions by different people in the past at the height of decadence and the disputes of the Umayyads called for Abbasid Caliphate as inevitable historical destiny the (Qaderi, 1996: 121). The difference between the Umayyads and Abbasids was the fact that the Umayyads employed the divine will in favor of historical appreciation to justify their legitimacy but the Abbasids cited the rightful inheritance of the Holy Prophet (PBUH) (Tabarsi, 1990: 421.7). The inheritance introduced them as righteous caliphs' chiefs (Qaderi, 1996: 121). The most important tradition cited by the Abbasids is the prophet's prediction that the caliphate would reach to his successors. It is noted that the prophet asked Abdollah to keep the father of kings (Ibn Taqtaqi, 1989: 191).

Muhammad ibn Ali ibn Abdullah ibn Abbas began to form a rise in the beginning of the second Hijri century. He sent Daiyans to khorasan, a place far from Damascus (the capital of the Umayyad Caliphs) because it had a wide area to the side of Muhammad (PBUH). The Persians, which called Abbasi Doa later, spoke first of corruption and oppression of the Umayyads and their inappropriate behavior by talking about the sons of the Prophet and desecration of the Kaaba and Medina (City of the Prophet), murder of sons the Prophet in Karbala. Zaid and Yahya spoke and invite people to a secret uprising (khajawiyan, 1997: 215). Bani Abbas claimed inheritance and succession of Abu Hashim, the son of Muhammad ibn al-Hanafiyyah. It is said that Abu Hashem called Muhammad ibn Ali, informed him from the secrets of Hashemiyans' invitation, assigned the power to him, and disclose the name of Alawite inviters who lived in Kofa; in this regard, the caliphate transformed from the Alawites to the Abbasids (Yaghoobi, 1987: 317). The point is that the idea of Abu Hashes who was an Alawite cannot be regarded as the idea of All Alawites because many groups were promoting Shitte sects and rose after the rise of the Abbasid. Hence, it is not reasonable to accept that Abu Hashem action is regarded as assigning right to caliphs from Alawite dynasty to Abbasid dynasty (Ibrahim Hasan, 1997: 30-31).

\subsection{The Abbasids' Invitation}

The Abbasids' approach in invitation was carrying out by selecting locations that were dissatisfied from the Umayyads; in addition, they choose the motto of "Satisfaction of the family of Muhammad" (Suyuti, 1425: 312; Khezri, 1999: 5). This 
multilateral motto played important role in creating unity among the true Alawi followers and supporters of the new movement because it eliminates any controversial discussion about the caliphate determination to ultimate victory (Dinwari, 1999: 332; Khezri, 1999: 5). Apparently, Muhammad bin Ali bin Abdullah bin Abbas was the chief in the invitation (to Satisfaction of the family of Muhammad). He tried in covert ways to invite people; he succeeded because of his alertness, ability and competence. After determining the leader and providing motion to accept the invitation, Khorasan appeared as territory and the Khorasanians were introduced as a revolutionary people to accept the change (Taqoush, 2004: 6).

Inviters began the invitation as merchants in Marw (Ibn Miskawayh, 1990: 2:412-413; Ibn al-Athir, 1385: 4/182). Then; they moved to Jorjan and other cities and villages of Khorasan. They called people to follow Muhammad (PBUH) with admirable perseverance. In a short time, the number of fans increased so that creating a more regular organization to communicate new supporters on the one hand and Abbasid leaders, especially Imam invited on the other hand was necessary (Tabari, 1990: 4/66). Hence, Abu Akramah Ziyad al-Hamdani, the head of Khorasan inviters, selected twelve Naqibs (captains) complying with way of the Prophet (PBUH) and the orders of Muhammad bin Ali. For greater certainty, he chose a successor for each Naqib to keep the unity in the event of the death or the resignation of Naqib (ibid: 2/297). These activities established the Abbasids' affairs in Khorasan so that Amara bin Yazid's conspiracy, also known as Khadash, failed to harm it (Moqadasi, 1919: 6/90; khezri, 1999: 6). Muhammad bin Ali declared his hatred of Khadash and his followers; he suggested for other inviters like Bokei ibn Maham and Soleiman ibn Kathir to continue their hiden invitation (Ibn al-Athir, 1385: 4/235). Muhammad ibn Ali died in 125 Hijri and the inviters' leaders pledged their allegiance to his son, Ibrahim (Yaqoubi, 1989, 2/332). By removing some of the restrictions, the new Imam strengthened the spirit of their fans; he announced that the movement would officially begin in 130 Hiji. He ordered Bokeir ibn Mahan to fly the black flag of Muhammad (PBUH) and wear black suits to mourn for Muhammad Ali. Bokeir died before the execution of the order and his son-in-law (Abu Salameh Khalal) accepted the responsibility (Khezri, 1999: 7). Meanwhile, the Eastern regions of the Islamic world were experiencing riots, which played significant roles in the victory of the Abbasids. First, a series of Khawarij's riots that began from Iraq and Hijaz and continued to Armenia and Azerbaijan. It preoccupied the Umayyads from 101 to 132 Hijri. Umayyad successive failures from Khawarij provided the opportunity for the development of missionary activity by Abbasi inviters (Yaqoubi, 1989, 2/329). Second, the uprising of Abdullah ibn Muawiyah, the grandson of Ja'far ibn Abi Talib in Muharram 127 Hijri in Kufa. Abu Moslem took the advantages of opportunity resulted from Abdullah ibn Muawiyah uprising, a group of Khawarij, and Nasr's clashes with Kermani in Khorasan. He came out of Marw by a bunch seventy of his followers under the pretext of Hajj in the spring of 129 Hiji (khezri, 1999: 10). On the 25th of Ramadan of that year, he flew the black flag of the Abbasids in a village called Sefidanj, near Marw; in this way, he uncovered his hidden invitation (Ibn al-Athir, 1385: 4/309). In 13th Shawwal 129 Hijri, the first battle between the Blacks and the Umayyad army in Khorasan ended by the defeat of the Umayyads. Abu Muslim began to purify his army from rebellious and suspected forces in Khorasan to show his important role in the movement and to consolidate the power of the Abbasids in Khorasan. In this way, his biggest excuse was Ibrahim's order indicating not trust the Arabs, kill everybody speaking in Arabic, murder any suspicious person, and respect Suleiman ibn Kathir (Bayat, 1991: 1034-1035). However, the purification, which mixed with suspicion of personal revenge and political competition, harmed Suleiman Ibn Kathir, Abu Salameh Khalal, and Abu Moslem who were the main founders of the Abbasid state (khezri, 1999: 13). The Abbasids' affairs were progressed until Ibrahim's letter to Abu Moslem was read by Marwan bin Muhammad. Ibrahim was captured and imprisoned in Harran in the year 131 Hijri. As ibrahim knew that he would not be freed assigned his invitation to Abdullah bin Muhammad. Ibrahim suggested for Abdullah to move to Kufa for his invitation. Ibrahim was murdered in $132 \mathrm{Hijri}$; in the same year, Abdullah bin Muhammad and other chiefs of Abbasid dynasty entered Kufa in Muharam. Abu Salameh Khalal kept the secret of their entrance and hid them in the house of Walid bin Saad (Yaqoubi, 1989, 2/345; Ibn al-Tiqtaqa, 146: 1998).

At the entrance of Abu Moslem's army leading by Hassan ibn Qahtaba to the gates of Kufa, the followers of Ale Abbas flew the flag of Abbasid army and expelled the Umayyad's agent from Kufa (Tabari, 1990: 4 / 344-346). After a slight hesitation, they chose Abu Abdullah bin Mohammed bin Ali bin Abdullah Abbas, known later as Saffah, as the first Abbasid Caliphate (Yaqoubi, 1989, 2/329). Saffah gave a sermon that is very famous for abundant of its promises. Then, he ordered his uncle, Abdullah bin Ali, with a massive army from the blacks to fight against Marwan (Massoudi, 1986: 3 I 266-270). Marwan began the war from Harran with his big army of Levant and the island residents. The two armies clashed near the river Zab (Tabari, 1990: 4 / 350-352). Marwan defeated and fled to Egypt in this battle. The last clash between the blacks and the Umayyad army was in Busir. Marwan killed in 132 Hijri and his head was sent to Saffah (Massoudi, 1986: 3 / 261-271). In any case, Abbasids succeeded to acquire the caliphate power by taking advantage of the decline of Umayyad government and their lack of legitimacy among the public, especially the lords. 


\subsection{The Iranians' role in the rule of the Abbasids}

It can be concluded that the Iranians had the most important role in the advent of the Abbasids. Historical reports indicate that in addition to the power issue, Abbasids required the Persians' experience in the administration of affairs because the Iranians had inherited the extended period of Sassanid government where government institutions were formed well. Thus, most ministers and their staff were Iranian in the first hundred years of the Abbasid caliphate. Ministers, namely, Abu Salameh Khalal, Khalid Barmak, Yahya ibn Khalid, his sons, and Abu Ayoub Moriyan had important roles in the developments at the first century of the Abbasid Caliphate. Although the Iranians, especially the Khorasanians, fought with Abu Moslem and brought Bani Abbas to government, many uprisings were carried out by the Iranians after revealing the deception of the Abbasids. Some of these uprisings and revolts aimed to avenge the killing of Abu Moslem by Bani Abbas. Factors underlie these revolts were:

1. Khorasanian Shiites's awareness of deception and misusing them to achieve power.

2. National tendencies with non-Islamic beliefs: they are called Bu Moslemiya or Abu Moslem's avengers such as Sinbad, Isaac Turk, Rawandiyeh, Estazesis, and Al-Moqane'.

3. Protesting against the ruthless tyranny by some Abbasid agents (Ibn Khaldun, 1984: 2/346).

\subsection{Classifying the History of Abbasid Dynasty}

Historians divide the Abbasid's rule into four ages based on the caliphate forces, the evolution of the political status, and prosperity of intellectual and cultural life

First era: the era of power, expanding and flourishing (132-232 Hiji).

Second period: The period of Turkish influence (232-334 Hiji)

Third period: the era of influence by Ale Buwayhid (334-447 Hijri)

Fourth period: the era of influence by Seljuk Turks (447-656 Hiji) (Taqoush, 2004: 27).

\subsubsection{First Abbasid Period (132-232 Hijri)}

This age began by the caliphate of As-Saffah and ended by the rule of Wathiq. Its main characteristics were powerful caliphate, its full independence, and the concentration of government forces in the hands of the caliphs. They had extraordinary administrative personal and political capability; they could maintain unity and suppress riots and rebellions. The Iranians were given a prominent place in the government during this time so that they overcome administrative and military apparatuses in Baghdad and the areas under their influence. They worked as commander of the army and administrative officials, ministry, teacher. They appointed in charge of other places as governor. The armies were caliphate helper and obedient tool in the hands of the Caliph. The army was governed by its caliphs. All this era caliphs were prominent: Abul Abbas, Mansour Mehdi Hadi, Haroun, Amin, al-Ma'mun, Mu'tassim and Wathiq. (Taqoush, 2004: 28).

\subsubsection{Second Abbasid Period (232-334 Hijri)}

This era began by the caliphate of Al-Mutawakkil and ended during the rule of Mustakfi. The main characteristic of this age was the weakness of the caliphate and the gradual disappearance of its awe so that the rulers decided about the separation of caliphate. At this time, Turks were ruling and the state apparatus were occupied by them (Khezri, 1999: 484). In the years 256-259 Hiji (during the rule of Mu'tamid, Mo'tazid and Muktafi), the caliphate recovered an important part of its power; this age is called "The Caliphate Awakening". These caliphs ruled in the second Abbasid period: Mutawakkil, Muntasir, Mosta'in, Mu'taz, Muhtadi, Mu'tamid, Muktafi, Muqtadir, Qahir, Radhi, Mutaqi, and Mustakfi. Ale Buwayhid was ruling in this time (Taqoush, 2004: 28).

\subsubsection{Third Abbasid Period (344-447 Hijri)}

This era began by the caliphate of Mustakfi and ended during the rule of Qaem. The main characteristic of this age was its relationship with the history of Buwayhid that had true influence and real power in Iraq. The Caliphs were only titled as the the caliphs but the real power belonged to Buwayhid. He could not interfere and manage the ruling affairs without their consent and approval. The caliphs had lost their influence that he was ordered and he carried out the orders; he had no religious domination over Buwayhid because their religion differed. They were Ghali Shiites and would be satisfied only for their own aims (Taqoush, 2004: 29). The caliphs of this age are Mustakfi, Muti'e, Tae'e, Qadir, and Qaem. 


\subsubsection{Fourth Abbasid Period (447-656 Hijri)}

This era began by the caliphate of Qaem and ended by the death of Mu'tassim. The main characteristic of this age was the transfer of real power to the Seljuk Turks that governed the lands of Jibal. The caliphate in the Seljuk governance was better than the Buwayhids' governance because they were Sunni and they maintained religious respect of the caliphs appropriate to their religious authorities. The caliphs of that period were not at the same level of ability and action. From the age of Mustarshid, they had revived some of their real power; they were independent in the government of Baghdad and its subsidiaries cities. Their power was revived during the rule of Nasir. They were surrendered by no king for 66 years untill the Mongols began their wide move to the West, occupied and destroyed cities. They finally arrived in Baghdad and dismantled the Abbasid Caliphate. The caliphs of this age are Qaem, Muqtada, Mustadhhir, Mustarshid, Rashed, Muktafi, Mustanjid, Mustazie, Nasir, Dhahir, Mustansir, and Mustasim (ibid: 29-40).

\section{Weakness and Decline of the Abbasids}

The main distinguishing element of first Abbasid era from later ages is the influence of Persians. This age began by the caliphate of As-Saffah and ended by the rule of Wathiq. Nevertheless, a new era with new details emerged since Mu'tassim and for the caliphate changes. The main features of this period caliphs' decline and the growing power of servants and courtiers who dominated powerless Abbasid caliphs, caught, imprisoned and tortured them, and even killed so cruel. In addition to the weakness of the Abbasid Caliphate, the emergence of this tragic situation resulted from the loss of Abbasids' power source because studying the rise of the Abbasids and their caliphate on the course shows that victory and authority of the Abbasid state indebted to factors such as the unwavering efforts of Iranians, support of parties and groups opposed to the Umayyads, regular and strong communication network among them Ale Abbas and the inviters, and a strong connection between the invitation and the Alawites Abbasids. Nevertheless, Ale Abbas destroyed their power source and helped to provide context of its weakness because they lost their support by treason in Iranians, killing Iranian leaders of the movement, and removal of large families and servants such as Ale Barmak and Sahl family. As well, they questioned their legitimacy by removing the Alawites and the suppression of their right uprisings. Everyone knew that Ale Abbas had taken advantage of the Alawites and linked his invitation to them to achieve victory; in this regard, they had proposed popular rituals and demands among the public (Khezri, 1999: 73). Communication networks among inviters and Abbasid caliphs were ruptured in this age because Abbasid caliphs murdered with guile and deception some of the inviter leaders for treason and dismantled the trust of its allies. In such situation, Muhammad, the son of Haron, called Mu'tasim billah, took the power. He required a strong army to establish security in the vast Abbasid territory suppress large riots and dangerous rebellions that occurred around while both the Iranians and the Arabs refused to cooperate with him. Thus, he turned to the Turks and created a new prejudice in addition to the Arabs and the Persians (Ibid: 74). He aimed to damage the leaders, Arab armies and traditional Mansour policy aiming to maintain the balance in the army between the Arabic and non-Arabic (Taqoush, 2004: 172). During his rule, his Iranian troops revolted and decided to govern Abbas al-Ma'mun, who had Iranian mother (Yaqoubi, 1987, 2/471). This event feared Mu'tasim greatly and he employed largly Turkish servants to be safe from Persian and Arab agitators because his mother was Turkish (Massoudi, 1986: 4/53). Mu'tasim also supported the Turks, chose his own guards from Turks, and gave them important positions and large provinces. This paved the way for their deadly grip, which resulted in weaknesses of the caliphate and the final fall (Khezri, 1999: 77).

In the political arena, he determined a center for them, established the city of Samarra, and settled them there. This policy has caused enormous harm to the Abbasid dynasty; it withdrew the caliphate from its Arabic-Iranian path and led to the weakening of the Caliphate (Taqoush, 2004: 173). After the death of Mu'tasim, his son Haron titled as Wasiq Allah came to power in 227 Hiji (Yaqoubi, 1987, 2/479). Wasiq had shouldered many responsibilities due to his fathers' order. Thus, he was familiar with Mu'tasim policy in the deployment of Turkish troops and tended to the Turks like his father; he even step further than his fathers' actions in this affair (Yaqoubi, 1987: 2/497). Wasiq died in 22 Hijri. He did not determine a successor. This led to a remarkable competition between the Turkish generals and the Abbasid political leaders to determine and select the desired caliphs. Finally, the Turks set their candidate, Al-Mutewakil al-Allah, as the caliph; it was their first interference in the determination of caliphate as the highest and most important power in the Muslim world. Their victory in this political competition left bad impacts on the way to determine the next caliphs because no caliph ruled without their consent until about a century later. Thus, the adverse effects of the domination of the Turks dominated on all levels of government and classes of society (Khezri, 1999: 90-91).

Turkish influence in the era of the Abbasid Caliphate ended during the Mustakfi age; the main characteristic of this age was the weakness of the caliphate and their power to intervene and influence on decision-making. From 334 to 447 
(the age of Mustakfi governance to the caliphate of Qaem) is called the age of Ale Buwayhid's influence. The main characteristic of the age was Buwayhids' domination over the Abbasid dynasty. Buwayhid Dynasty was founded by Bouyeh's children. When the Abbasid caliphate weakened and declined in the third and fourth centuries and local rulers and ruling dynasties of each area claimed independence, the idea of a strong state and the revival of the ancient heritage of the many ethnic groups spread, which resulted in the establishment of the states such as Safarian, Samanids and Ziyarid. Meanwhile, the Shiite family of Bouyeh, which had been risen from rebellious tribes Deylam, was more successful than the other groups (Ibid: 143). The 113-years governance of the Buwayhids coincided with caliphate of five Abbasid caliphs who lived ceremonial and officially with wages by the Commander of the Buwayhids. In 47 Hiji in the age of Qaen Billah, Buwayhids were overthrown (ibid: 163). Since 447 Hijri, the influence of Seljuks over Abbasid Caliphate began. The influence began in the age of Qaem and ended by the murder of Musta'sim by Hulagu Khan in 656 Hijii. This age is similar to the east of Islamic word with respect to the concentration of Seljuks who was successor of Buwayhid. In this way, they spread their power over caliphate destiny by respecting to the caliphs and center of caliphate. The relationship between caliphs and Seljuks varies from fruitful cooperation to outright hostility, especially in the age os Seljuks' separation and non-integration. While the caliphs desired to free themselves from the Seljuk bounds, they were incapable to prevent unrests caused by the involvement of the Seljuk dynasty. This invoked Abbasid caliphate to call for Khwarazmshahs' help for victory. Their incapability caused their clashes with the newcomers (Khwarazmshahs) because they sought domination on powers and duties the caliphate. Then, for freedom from Khwarazmshahs' domination, they resorted to the Mongols whose main features were violence and brutality (Taqoush, 2004: 9). Leading by Hulagu Khangrandson of Genghis Khan- came to overthrow Abbasid caliphate after conquering many parts of Iran. The last Abbasid caliph (Musta'sim) was not ready to repel the Mongols' attacks. After his victory over Isma'ilism in Iran, Hulagu Khan wrote a threatening letter to the caliph. The caliph refused with threatens while his Shiite minister ibn Alqami believed that the caliph should remove their attack by sending some gifts. Some courtiers opposed the minister and the caliph accepted the later idea. Finally, Baghdad was besieged by Mongols and the Abbasid caliphate submitted due to the promise of safe by Hulagu. By his murder, the Abbasid caliphate fell after more than five centuries of domination over the Muslims (ibid: 297-301).

Domestic factors had brought the Abbasid caliphate to ruin from the inside it before the fall of the Abbasid Caliphate by foreign forces. These factors include:

1. Drinking and sensuality, Orgy, unemployment and the weakness of the caliphs and other rulers of the country.

2. The rise of weak and weak-minded persons who sought refuge in forbidden pleasures instead of the problems of the country.

3. Increasing wealth, comfort and popularity of the handmaids' affairs in the ruling class that its destructive influence harmed other classes of people, and destroyed their military virtues.

4. Many riots emerged due to ethnic and geographical disputes. Arab and Persian, Shami, Berber, Christian, Jewish and Turkish individuals were unanimous in humiliating each other.

5. Negligence in irrigation works had a great effect in the weakness and corruption of the government; it led to problems in agricultural production.

6. Schism in Islam made political problems more difficult with the emergence of various denominations.

7. Farmers, merchants and artisans whose efforts was ignored by the governor did not show any interest in labor and initiation so that the government's revenue was fewer that its expenditure and the heads of government failed to afford the army to dominate it.

8. The presence of the Turks in the army, which had been replaced to the Arabs, was conducted by Turks from the age of Mu'tasim to the end of Abbasid era.

9. The caliphs' palaces were centers for humble conspiracy, bloodshed and murder while the governors shouted freedom. They tried to keep their position for all their lives (Nozari, 2009).

\section{Conclusions}

With an overview of the history of the Abbasid Dynasty from start to fall, it is clear that the more-than-five hundred governance resulted in a pervasive revolution in the history of Islam and turning point in Islamic developments that changed Muslim community basically. The Abbasids could earn the power of caliphate after years of efforts, with the help of Alawites and Iranians using all the subtlety, a highly disciplined and unique organization in the history of Islam, and dependence on family of prophet hood as well as people's dissatisfaction with the Umayyads dynasty through deceptive motto. Before reaching the power, they sought God's satisfaction at the first level and social justice in the second level. Nevertheless, they not only ignore social justice but also violate the rights of the closest persons to God and his prophet 
(Alawites). They betrayed to the Iranians who had the most important role in this victory. The frauds and the consequent riots by the Iranians against the Abbasids led them to decline. Because of the incompetence of some of the caliphs and lack of support by old friends (the Iranians and Alawites), they their extended their helping hand to the external agents; in this way, they were under the domination of Turks, the Buwayhids, and Seljuks for three ages while they had the least authority. All the factors came together to collapse the government with the Mongol invasion and the murder of the last Abbasid caliph.

It is evident that the most important and basic factors for the collapse of the government are their deceptions in the first place, incompetence of some of the Abbasid caliphs, and free interference in governmental affairs by foreign agents.

The historical references of the past and the present indicate that the history of Islam requires a comprehensive and specialized scientific research in this regard to study Abbasid age from rise to fall. Historians have analyzed some elements of the Abbasid history while its first period has been included more than other periods. It seems further researches should be conducted on the history of Abbasid era with focus on the last period of the age.

\section{References}

Ibrahim Hasan, Hasan (1997). The political history of Islam. Abolghasem Payandeh, Tehran Javidan publication. Ibn al-Athir, Ezzedine (1385 Hiji). The Complete History. Beirut: Dar Sadir Publication.

Ibn Khaldun, Abd al-Rahman ibn Muhammad (1984). Al-'Ibar: tärīkh-i Ibn Khaldūn. Trans. Abdul Muhammad Ayatolahi. Tehran: Publication of culture studies and research.

Ibn Taqtaqi (Ibn tabataba) Muhammad ibn Ali (1989). Fakhri History. Tehran, scientific and cultural publications.

Ibn Miskawayh Ahmad ibn Ali (1990). Tajārib al-umam. Trans. Alinaqi Monzavi. Tehran: Tous Publication.

Bayat, Azizollah (1991). History of Iran: From the emergence of Islam to Diyalameh, Tehran Shahid Beheshti University.

Khezri, Ahmadreza (1999). History of the Abbasid caliphate from start to end of the Buwayhids. Tehran: SAMT.

Khajavian, Muhammad Kazim (1997). History of Shia. Mashhad: University Publication.

Dinwari, Ahmad (1999). Akhbār al-țiwāl. Trans. Mahmood Mahdavi Damghani. Qom, Nei publication.

Dhahabi, Shams al-Din Muhammad (1987). Tarikh Islam Woufyat Almshahir Wala'allam. (Ed) Omar Abdul Islam Toomari. Beirut: Dar alKitab al-Arabi.

Suyuti, Abdol Rahman ibn Abi Bakr (1999). Tareekh UI Khulafa. Research by Salih ibrahim. Beirut: Dar Sadir Publication.

Tabari, Muhammad ibn Jobeir (1990). Tabari History. Abolghasem Payandeh, Tehran: Asathir publication.

Taqoush, Muhammad Soheil (2004). The Abbasid State. Trans. Hojjattollah Joudaki, Qom: Institute of seminary and university.

Qaderi, Hatam (1996). Evolution in the Abbasid Caliphate from Start of Legitimacy to Collapse of the Foundations. Tehran: Bonyan Publication.

Massoudi, Abul Hassan Ali Bin Al-Hussein (1986). Meadows of Gold and Mines of Gems. Trans. Abolghasem Payandeh, Tehran: Scientific and cultural publications.

Mufid, Abi Abdollah Muhammad (1986). Jamal Battle. Trans. Mahmood Mahdavi Damghani, Tehran: Nei Publication.

Moqadasi Muhammad ibn tahir (1919). Kitab al-Bad wa-al-tarikh. Cairo: Maktab al-Thaqafe al-Diniyeh.

Nozari, Ezatollah (2009). A social history of Iran: From the beginning to the constitution, Tehran: Khojasteh.

Yaqoubi, Ahmad ibn Yaqoub (1989). Yaqoubi History .Trans. Muhammad Ibrahim Ayati, Tehran: Scientific and cultural publications. 